\title{
Role of stakeholders in business rescue
}

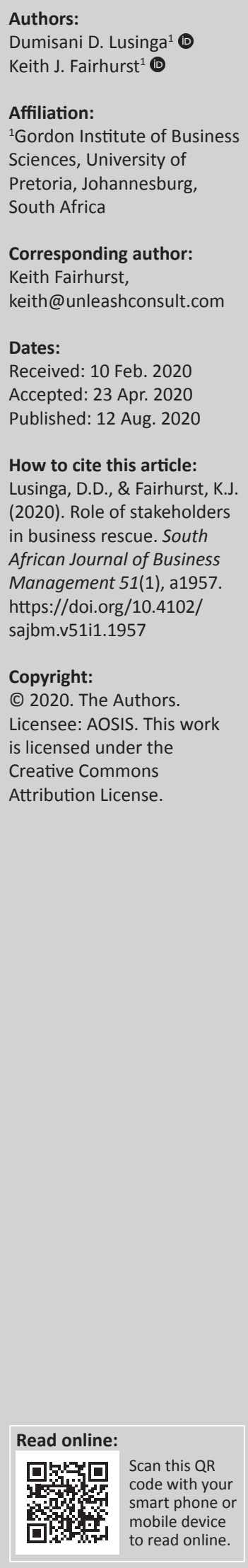

Purpose: It is widely accepted that stakeholders play a role in the turnaround of an organisation. However, the exact role is unclear. This study set out to investigate the roles of stakeholders in the success of business rescue through the lens of stakeholder theory.

Design/methodology/approach: The study research design is qualitative following an exploratory approach. The choice of technique for the study was semi-structured interviews.

Findings/results: The findings indicate that key stakeholders go beyond affected parties as described by Chapter 6 of the Companies Act. Creditors are considered the most influential stakeholders due to their ability to vote on the business rescue plan, followed by postcommencement funders and employees, to ensure business continuity. Customers were given the same level of importance by the business rescue practitioners as other affected parties. Due to the dynamic nature of business rescue, business rescue practitioners prioritise resourceful stakeholders when managing the process. A simplified framework illustrating roles of stakeholders during business rescue is presented.

Practical implications: Stakeholder management should be recognised as a valuable exercise that must be allocated time and resources. Business rescue practitioners should recognise stakeholder influences at different stages of the business rescue process.

Keywords: business rescue; stakeholder theory; affected parties; stakeholders; business rescue practitioner (BRP); post-commencement finance (PCF).

\section{Introduction}

The business rescue status quo report reflected a $9.4 \%$ success rate in business rescue (Pretorius, 2015). With South Africa's unemployment rate currently standing at $26.7 \%$ (Statistics South Africa, 2017), understanding that business survival plays a significant role in countering unemployment is important. Business rescue provides an opportunity to save jobs that would be lost through business failure, provides the shareholder with the prospect of getting a return on their investment and enables creditors to maximise their return (World Bank, 2015). Conradie and Lamprecht (2015) posit that successful business rescue proceedings have a positive impact on South African business in general and positive spin-offs for different stakeholders such as creditors, workers and customers. Furthermore, D'Aveni and MacMillan (1990) and Trahms, Ndofor and Sirmon (2013) recognise how crucial stakeholders are in the turnaround of a business. It is, therefore, valuable to understand stakeholder influence in the success and failure of business rescue.

Priego, Lizano and Madrid (2014) argue that stakeholders may contribute significantly to reduce the prospect of business failure. In addition, Tangpong, Abebe and Li (2015) acknowledge external stakeholder support as valuable when stabilising a corporate during the corporate decline phase. Furthermore, Benedettini, Neely and Swink (2015) identify the business environment incorporating stakeholders as a factor that contributes to business failure. These researchers (Benedettini et al., 2015; Priego et al., 2014; Tangpong et al., 2015) show that stakeholders play a prominent role in an organisation's failure and turnaround processes.

Smith and Graves (2005) note that it is unclear precisely what role stakeholder support plays within the decline and turnaround process of an organisation. Pajunen (2006) highlights that although much has been written on business failure and turnarounds, practically no research investigates stakeholder influences within corporate failure and turnaround. Furthermore, while 'stakeholders are addressed within the literature, stakeholder theory remains underutilised' (Trahms et al., 2013, p. 1297). Decker (2016) concurs; despite stakeholders possessing resources to support an organisation in decline, there is limited evidence of stakeholders' actual roles in a turnaround. To further consolidate the need for research Ghazzawi (2017) suggests investigating how the power of stakeholders may interfere with the organisation's decline and turnaround 
efforts. In summation, it is clear that literature recognises the importance and contribution of stakeholders. Yet, it remains unclear precisely what roles different stakeholders play within turnarounds.

Within the South African context, the legal and formal turnaround process an organisation would follow is referred to as business rescue. Business rescue is a formal process governed by Chapter 6 of the Companies Act. It is distinct from informal turnaround, where creditors and financial institutions may collaborate to provide financial assistance to aid the company's recovery (Levenstein, 2016). Pretorius (2013) likens business rescue literature to turnaround literature, the former being formal and usually done when the business is in its later stages of decline. Since business rescue as a phenomenon has limited literature, turnaround literature is often used as a guide (Pretorius, 2013). Similarly, little research has been done to uncover the influences and roles of stakeholders in business rescue in South African organisations (Pretorius, 2013). Therefore, there is benefit to understanding stakeholders' roles in business rescue in South Africa.

\section{Research objectives}

This study seeks to understand how stakeholder theory can be utilised in business rescues to facilitate successful turnarounds. The study examines the behaviour and power dynamics of stakeholders in declining businesses, with the understanding that stakeholder collaboration may result in a better chance of success in business turnarounds (Priego et al., 2014). Although stakeholder power means that the stakeholders with power may be influential in business rescue proceedings, resources and network influence along with other factors are also important sources of power (Pajunen, 2006).

The study's primary research question is: what are the roles that different stakeholders play during a period of successful or unsuccessful business rescue in South African organisations? The study seeks to understand within the context of business rescue who the key stakeholders are, which stakeholders are influential and what factors contribute to their influence.

\section{Literature review}

Faced with financial distress, business rescue proceedings can be commenced if there is reasonable prospect that the company can be rescued from failure (Le Roux \& Duncan, 2013). The business rescue proceedings can be initiated voluntarily by the company directors through a board resolution or by a court order brought about by affected parties (Conradie \& Lamprecht, 2015). Section 128 of the Companies Act defines affected parties as registered trade unions, employees, creditors or shareholders of the company (the Companies Act, No. 71 of 2008).

Section 133 of the Companies Act provides a stay or moratorium on legal proceedings. Levenstein (2016, p. 12) likens the moratorium to 'breathing space' provided to an organisation in decline. Accordingly, no legal proceedings may be brought against the company during the business rescue proceedings except under conditions provided by section 133(1)a-e.

The business rescue plan is considered one of the key activities carried out by the business rescue practitioner (BRP) and is integral to the business turnaround process. Once business rescue proceedings have commenced and the temporary moratorium becomes effective, the BRP must develop and implement the business rescue plan (Le Roux \& Duncan, 2013). The plan should display how the company will be rescued and should reflect the rehabilitation activities to be carried out, for example restructuring the business, requesting additional funding and paying debt obligations (Pretorius \& Rosslyn-Smith, 2014).

Pretorius and Rosslyn-Smith (2014) argue that affected parties, who can be viewed as stakeholders, play a role in the proposal and adoption of the plan. The rescue plan must be approved or rejected by affected parties. It is useful to understand the power dynamics at play between parties during the rescue proceedings.

\section{Powers and rights of affected parties}

The rights and powers of affected parties are detailed in section 144 to 146 of the Act. Salient points include the fact that shareholders have limited powers and rights when compared to employees and creditors. Shareholders are generally not consulted on the business rescue proceedings by the BRP and, unlike creditors and employees, cannot form a committee. (Jijana, Chetty, \& Karodia, 2016). Additionally, shareholders may not vote on approving the rescue plan unless the shareholder is voting as a creditor or the proposed rescue plan impacts their shareholding (Levenstein, 2016).

Creditors are relatively influential in business rescue proceedings as the final vote to approve the plan lies with them (Le Roux \& Duncan, 2013). In terms of section 152, the business rescue plan must be approved through a vote by more than $75 \%$ of the creditors of which $50 \%$ of the votes must be from independent creditors. Le Roux and Duncan (2013) argue that creditors have various responsibilities and powers within the proceedings as they can influence the key elements of the business rescue proceedings and ultimately creditors have the power to accept or reject the plan.

In conclusion, affected parties have rights and powers that are legally protected. The legal process makes provision for only employees, trade unions, creditors and shareholders.

\section{Business rescue practitioner}

The principal objective of the BRP is to rescue a company that is financially distressed. In achieving this objective, which includes providing relief to affected parties, the BRP's rescue plan is important (Pretorius, 2014). The BRP 
has complete control of managing the affairs of the company and replaces the current board or management of the company (Pretorius, 2013). Pretorius (2014) argues that selecting a suitably qualified BRP is important in the success of the business rescue. Levenstein (2016) further questions the appointment of practitioners who lack expertise or have limited education.

The ethics of the BRP are of paramount importance as there are opportunistic BRPs who focus 'on the "profit opportunity" and uncertainty that emanates from the business rescue environment' (Levenstein, 2016, p 592). Bradstreet (2010) goes a step further, indicating that the appointment of any 'loose cannon' practitioners creates a risk as creditors may not provide finance to support the operations (Bradstreet, 2010, p. 212).

In December 2017 the 'Diener judgement' was made. This judgement was related to BRPs receiving their fees and expenses when the business rescue has failed and the company goes into liquidation. The judgement was that, if the company goes into liquidation, the BRP must prove their claim for fees and expenses with the liquidators and there is no special preference afforded to the BRP over secured creditors (Braatvedt, 2017). Essentially, the judgement means that BRPs must carry out an objective pre-assessment of the distressed company to assess if the company will be able to pay the BRP's fees and expenses before accepting the assignment (Braatvedt, 2017). Consequently, the judgement may curtail the 'loose cannons' as identified by Bradstreet (2010).

\section{Stakeholder theory}

\section{Identification, classification and influence}

When in decline and attempting a turnaround, stakeholders play a valuable role in a company's recovery (Trahms et al., 2013). Stakeholder theory provides a theoretical base to assess how the relationship between a company and its pivotal stakeholders can strategically improve the company's performance (Freeman, Harrison, Wicks, Parmar, \& De Colle, 2010). To explore the identification and influence of stakeholders in business rescue, stakeholder theory is used as the guiding lens.

At the outset, it is valuable to recap the key definitions of stakeholders as they have evolved with stakeholder theory (Mitchell, Agle, \& Wood, 1997). The classical theory by Freeman (1984) outlines stakeholders as any group that can have an influence on or can be influenced by the organisation's objectives. Clarkson (1995) further defines stakeholders as a group that can have a claim, ownership, rights and interest in an organisation and its operations. In later years, the classical definition by Freeman remains the most broadly acknowledged definition of a stakeholder (Fassin, 2009).

Donaldson and Preston (1995) identify three fundamental approaches in classification and identification of stakeholders. The first approach is instrumental stakeholder theory, based on the economic model of stakeholder identification. The second, seen as the most fundamental, is the normative view which adopts the ethical view argument of cooperation and community. The third, based on how stakeholders are actually managed in practice, is the descriptive stakeholder theory. Mitchell et al. (1997) presented a model that categorises stakeholders through their control of power, legitimacy and urgency. The model by Mitchell et al. (1997) is criticised for overlooking the distinct levels of the characteristics and the challenge of separating power and legitimacy in practice (Pajunen, 2006).

Friedman and Miles (2002) addressed some of the limitations of earlier models by assigning stakeholders into four categories based on stakeholders' compatibility or incompatibility and whether the relationship between the company and the stakeholders is necessary or contingent. This model attempts to address the question of why some stakeholders have more influence and legitimacy over organisations.

Pajunen (2006) created a model referred to as the 'model for stakeholder influence identification' which demonstrated that stakeholders' identification and influence during corporate survival is in the form of direct resource dependence and network position-based types of power. The model classified stakeholders into three categories: governing stakeholders, potential stakeholders, and minor stakeholders with no influence. The study carried out by Pajunen revealed that shareholders usually have resource dependence power based on the resources, knowledge of the firm and the ability to provide finance during the organisation's decline. Additionally, network-based influence emanates from an intermediary stakeholder with the ability to link other stakeholders and become the focal point regulating information and resources (Pajunen, 2006). The model by Pajunen provides a theoretically robust method to define and identify stakeholders that are influential during the organisation's decline.

Mainardes, Alves and Raposo (2012) carried out a study with the aim to overcome the limitations of the earlier stakeholder models, namely the classification model by Mitchell et al. (1997). The model identified six stakeholder classes which were dependent, passive, partner, controller, regulator and non-stakeholders. Miles (2017) looked at producing a thorough, all-inclusive stakeholder theory after the review of 593 various stakeholder theory definitions. The classification model suggested four superordinate terms relating to stakeholder classification and identification, namely influencers, claimants, recipients and collaborators.

Given the different classifications of stakeholders provided by Mitchell et al. (1997), Pajunen (2006) and Friedman and Miles (2002), Miles (2017) argues that the multidimensional classification is more comprehensive and pragmatic in consolidating, clarifying and ordering the concepts of stakeholder classification and identification.

In conclusion, it is noted that different stakeholders yield power, resources, network positions and compatibility which may be influential when the company is in business rescue. Stakeholder identification and classification is therefore 
relevant in tackling organisation decline. Additionally, early involvement and identification of stakeholders is beneficial to success in the turnaround process (Decker, 2016). Benefits are sought by managing all key stakeholders proactively during the decline of the organisation rather than focusing on one stakeholder to the detriment of the others (James, 2016). In relevance to the study, stakeholder identification, influence and classification seeks to address the first and second questions of the study.

\section{Employees, management and turnarounds}

Employees play an important role in the success of business rescue and there is consensus that a successful business rescue will result in preservation of jobs (Conradie \& Lamprecht, 2018; Levenstein, 2016; Pretorius 2015).

Trahms et al. (2013) puts forth that top management play a crucial role in the efforts of a business in distress and that management's cognition and subsequent turnaround actions result in better opportunities for turnaround. Alternatively, employees and top management may not support recovery efforts. Therefore, it is essential to understand the role of employees and top management in a successful turnaround.

\section{Turnarounds and stakeholders}

Consideration of multiple stakeholder roles is necessary during the decline and turnaround of an organisation (Trahms et al., 2013). While Chapter 6 focuses on affected parties, stakeholders are not defined but only mentioned once in the purpose of the Act which seeks to ensure that all rights and interests of all relevant stakeholders are catered for during the business rescue process (the Companies Act, No. 71 of 2008). However, Chapter 11 of the United States Bankruptcy Code allows for the comprehensive management of stakeholders other than suppliers and equity holders, including key stakeholders, such as customers, trading partners and employees (James, 2016). Ghazzawi (2017) suggests consideration be extended to stakeholders such as government and the general public. The contrast between Chapter 6 and Chapter 11 reinforces the research question which seeks to understand which stakeholders are taken into account during the business rescue process.

\section{Business rescue and stakeholders}

Rosslyn-Smith and Pretorius (2015) investigated stakeholder expectations of the business rescue plan from a South African perspective. They acknowledge that the business rescue plan legally recognises affected parties. Other stakeholders are accounted for through section $7(\mathrm{k})$ of the Companies Act, which requires business rescue to balance the rights and interests of all relevant stakeholders (Rosslyn-Smith \& Pretorius, 2015). Given that regulatory authorities and other external stakeholders like special interest groups are not specifically addressed in business rescue legislation, their omission may be detrimental to the turnaround effort (Rosslyn-Smith \& Pretorius, 2015). An example of this would be tax authorities; Du Preez (2012) noted that there is uncertainty on the ranking of taxes in business rescue whether looking through the lens of business rescue or the Insolvency Act. Levenstein (2016) further commented that the South African Revenue Services (SARS) is ranked on par with other creditors in business rescue, while viewed as preferent in liquidation the SARS may consider liquidation as opposed to business rescue when voting as a creditor. Regulators such as the SARS can have a material impact on business rescue.

The dynamics at play in business rescue are captured by Pretorius (2016) in a paper refuting business rescue as being debtor friendly. Ghazzawi (2017) noted that the presence of various stakeholders presents a predicament in managing stakeholders' relationships in an organisation decline and turnaround. This problem is demonstrated by Pajunen (2006) who indicated that stakeholder resource-based power is evident at the beginning of the decline and that stakeholders slowly lose power as the decline continues. The relationships and interactions of these stakeholders differed at various stages of the turnaround process indicating the complexities experienced during an organisation's decline and turnaround.

From a South African background, Pretorius (2016) considered agency relationships within the context of business rescue, with agency theory assisting in understanding some of the stakeholder relationships in business rescue. The studies of Rosslyn-Smith and Pretorius (2015) and Pretorius (2016) inform aspects of the study but have no direct link with the research question, and this reinforces the need for the study.

\section{Post-commencement finance}

Creditors, providers of capital and banks have a useful role to play as they have power and influence during the decline phase of the business (Ghazzawi, 2017). Within the context of business rescue, it is imperative to note that secured and unsecured creditors may have equal voting rights; the voting rights are based on the value of the amounts outstanding (the Companies Act, No. 71 of 2008). Subordinated creditors, however, have voting rights based on the appraisal by the BRP based on the amount the subordinated creditor would receive on liquidation (Jijana et al., 2016).

Pretorius (2016) views secured creditors as more powerful when compared to the other stakeholders; specifically noted are the banks which are seen to hold the key to the success of business rescue. Decker (2016) also supported the view of banks being powerful due to their extensive resources. Le Roux and Duncan (2013) emphasised the influence of secured creditors, suggesting that secured creditors have protection in the rescue process and usually the secured creditors are not concerned with post-commencement finance (PCF), while unsecured creditors may lose significantly in the case of liquidation.

Pretorius and Du Preez (2013) note that PCF is a valuable ingredient to achieve a successful business rescue. 
Rosslyn-Smith and Pretorius (2015) and Levenstein (2016) support this view and further argue the importance of PCF for business continuity. Levenstein puts forth that 'PCF is the lifeblood of the company while it is undergoing its restructuring process under business rescue' (Levenstein, 2016, p. 474). Thus PCF granted may have an impact on the success of the business rescue and key stakeholders may have a role to play in providing PCF. The question of the power dynamics between stakeholders in business rescue proceedings remains valid and is the focus of research question three of this study.

\section{Research methodology}

The research design is qualitative following an exploratory approach. The technique for the study was semi-structured interviews. Interview subjects were asked questions about stakeholders within business rescue and the influence and power dynamics that play out during the process.

In qualitative studies carried out by Pretorius and Du Preez (2013) and Conradie and Lamprecht (2018), the studies used BRPs as they were seen as subject matter specialists with experience and knowledge. Thus, the population of the study is BRPs as defined by Chapter 6 of the Companies Act.

Purposive sampling was applied and BRPs were selected based on their knowledge and experience in the field (Elo et al., 2014). A request was made to the Turnaround Management Association - South Africa (TMA-SA) for a list of registered BRPs. Using a random number generator, $12 \mathrm{BRPs}$ were selected. Of the $12 \mathrm{BRPs}$ selected, not all were able to participate in the study. Therefore, both judgemental and snowballing sampling techniques were utilised to get the final sample size of 13 BRPs.

In-depth, semi-structured interviews were used to collect data. In total, 13 semi-structured interviews were conducted with BRPs with different ranges of experience. Mapping the questions to the propositions allowed for quality data collection. The interview questionnaire was used as a guide. Additional questions were asked and answered where necessary to develop further understanding and to obtain relevant information. As noted by Saunders and Lewis (2012), the researchers can adapt the interview questions where required.
Data analysis according to Zikmund, Babin, Carr and Griffin (2013) focuses on identifying key features, patterns and insights from analysed data collected. In this study a thematic analysis was used. Themes from the interview data were identified and examined to report patterns concerning the research question (Braun \& Clarke, 2006). Transcription and data analysis were carried out soon after the interviews to ensure that the researcher was immersed in the data.

\section{Research questions and propositions}

Table 1 details the research propositions and how they link to the interview questions.

\section{Research results and discussion Research proposition 1: Key stakeholders involved in the business rescue process go beyond the affected parties as described by Chapter 6}

The proposition seeks to address the notion that stakeholders are the only affected parties. In our findings the three main themes identified were affected parties, broad view and parties influenced by an outcome.

\section{Stakeholder definition}

The themes shown in Table 2 relate to BRPs' understanding of stakeholders in business rescue.

Rosslyn-Smith and Pretorius (2015) acknowledge affected parties as stakeholders but notably recognise all other stakeholders as stakeholders through section $7(\mathrm{k})$ of the Companies Act, which requires business rescue to balance the rights and interests of all relevant stakeholders. As noted by Fassin (2009) the classical stakeholder theory by Freeman (1984) remains the widely used definition. The definition incorporates the broad view of stakeholder management as indicated by the views of the participants. The findings indicate that the first instinct of the participants was to describe stakeholders as affected parties; however, through further probing, reference was made to the broad view and parties were influenced by the outcome of the business rescue.

The findings demonstrate that the affected parties are seen as the primary stakeholders. It could be argued that the BRP's primary focus is the affected parties and that, as noted from section 144 to 146 of the Companies Act, the affected parties

TABLE 1: Research propositions

\begin{tabular}{|c|c|}
\hline Proposition & Interview questions \\
\hline $\begin{array}{l}\text { Proposition 1: } \\
\text { Key stakeholders involved in the business rescue process go beyond } \\
\text { the affected parties as described by Chapter } 6 \text {. }\end{array}$ & $\begin{array}{l}\text { Who are the key stakeholders involved in the business rescue process that an organisation goes through? } \\
\text { - What is your understanding of a stakeholder within business rescue? } \\
\text { - Wow do you identify stakeholders? }\end{array}$ \\
\hline $\begin{array}{l}\text { Proposition 2: } \\
\text { Stakeholders with the largest material claim are the most } \\
\text { influential in the business rescue process. }\end{array}$ & $\begin{array}{l}\text { Which stakeholders are influential in business rescue processes? } \\
\text { - Within the realm of business rescue, do you prioritise stakeholders? } \\
\text { - How would you rank the listing of stakeholders in terms of influence? } \\
\text { - Why do you consider a stakeholder or a group influential? }\end{array}$ \\
\hline $\begin{array}{l}\text { Proposition 3: } \\
\text { Size of the claim, resources, networks, post-commencement } \\
\text { finance, creditor security, and rankings of creditors determine } \\
\text { influence during the business rescue process. }\end{array}$ & $\begin{array}{l}\text { What factors contribute to stakeholder influence? } \\
\text { - Given that the stakeholders are influential, what basis or process do you follow to make your } \\
\text { determination? } \\
\text { - What drives stakeholder power in business rescue? } \\
\text { - Are given drivers or factors considered in isolation? } \\
\text { - What is your view of the influence of personal surety by shareholders and subsequent behaviour by }\end{array}$ \\
\hline
\end{tabular}


TABLE 2: Response to definition question

\begin{tabular}{lc}
\hline Theme & Respondents (\%) \\
\hline $\begin{array}{l}\text { Theme identified: Affected parties } \\
\text { Referred to affected person in definition question }\end{array}$ & 76.92 \\
Made other references in the definition question & 23.08 \\
Theme identified: Broad view & \\
Referred to a broad definition & 53.85 \\
Did not refer to a broad definition & 46.15 \\
Theme identified: Parties influenced & \\
Made reference to an influenced party in the definition & 53.80 \\
Did not make reference to an influenced party in the definition & 46.15
\end{tabular}

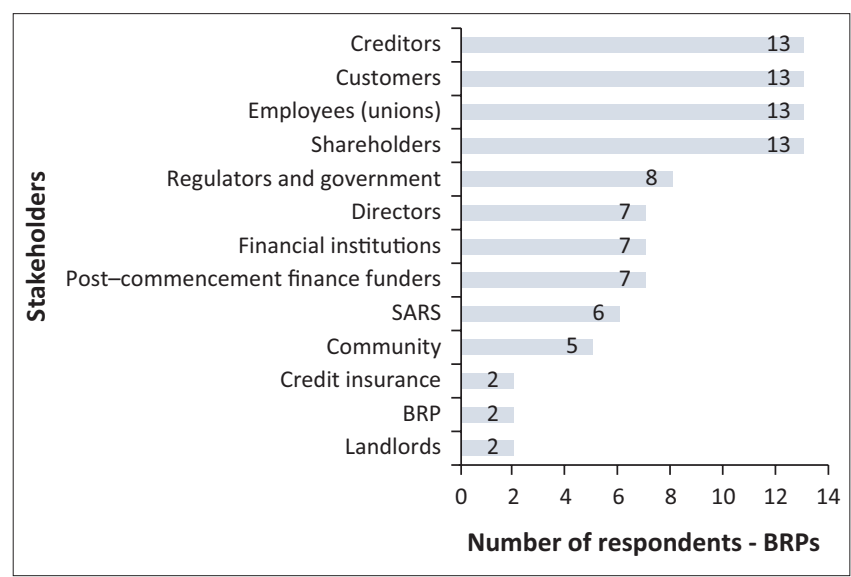

BRP, business rescue practitioner; SARS, South African Revenue Services

FIGURE 1: Key stakeholders identified by business rescue practitioners in the data collection phase.

have rights and powers that are protected by legislation. This view supports the work by Rosslyn-Smith and Pretorius (2015).

\section{Stakeholders identified}

To adequately answer the research question, it is important to understand who the key stakeholders are that BRPs consider in the process of ensuring that the business rescue process is successful. Although stakeholders vary from case to case, the BRPs provided a list of stakeholders they considered to feature prominently in the business rescue proceedings they had been a part of.

From a literature perspective, Donaldson and Preston (1995) identified three approaches to identifying stakeholders: the instrumental, normative and descriptive view. There is limited evidence that the BRPs use the normative view and the descriptive view. The instrumental view, which considers the economic and financial views in the determination process of identifying stakeholders according to Donaldson and Preston (1995), and the resource-based view, which focuses on stakeholders who contribute with resources as argued by Pajunen (2006), are more pronounced in the findings.

All the respondents included creditors, employees (unions) and shareholders as stakeholders, which aligns to the affected party definition in the Act. Observations from Figure 1 indicate customers and government or regulators are seen to also rank highly as stakeholders. This demonstrates that stakeholders extend beyond affected parties. Customers unexpectedly have the same number of respondents as affected parties. From literature, Freeman (1984) noted general stakeholders to include customers. While in studies regarding turnarounds or business rescue, James (2016) and Levenstein (2016) consider customers as key stakeholders. Business rescue literature does not appear to cover customers and their impact on a successful business rescue. Based on the findings a valid question is whether customers should also be considered affected parties.

\section{Research proposition 2: Stakeholders with the largest material claim are the most influential in the business rescue process}

Research proposition 2 sets out to understand which stakeholders the BRPs consider to be the most influential in the success of the business rescue. Before determining which stakeholder is influential, it is important to understand whether the BRPs prioritise stakeholders. After determining whether the BRPs prioritise stakeholders, the next step is to identify how BRPs rank the stakeholders in terms of influence and finally conclude with why the stakeholders are considered influential.

\section{Stakeholder prioritisation}

This aspect of the findings intends to establish the approach by BRPs on prioritisation of stakeholders in the realm of business rescue. In line with stakeholder theory, once stakeholders are identified, it is important to prioritise them such that emphasis is placed on relevant stakeholders to ensure success.

The findings indicated that $62 \%$ of the respondents prioritise stakeholders, while $31 \%$ took a balanced approach without prioritisation and $7 \%$ focused on prioritising employment. Employment emerged from the discussions on prioritisation. The BRPs indicated that preserving jobs was one of their leading priorities.

The views of the participants and the literature are aligned in respect of prioritisation of stakeholders. Mainardes et al. (2012) and Miles (2017) prioritised according to influence and Henisz, Dorobantu and Nartey (2014) took the instrumental view in prioritisation; however, James (2016) advocates for the management of all stakeholders proactively but acknowledges that it is not always possible, thus one may need to prioritise. The views of the participants in favour of prioritisation are in line with the literature; however, it is also important to discuss the views of the participants that take the alternative view, the balanced approach.

Approximately a third of the participants took a balanced approach to managing stakeholders in business rescue. The approach taken by the respondents is in line with section $7(\mathrm{k})$ of the Companies Act which requires the business rescue to balance interests and rights of all stakeholders (the Companies Act, No. 71 of 2008). Within literature, the balanced approach is supported by Harrison, Bosse and 
Philips (2010) in the context of stakeholder theory by arguing that the broad stakeholder approach results in the organisation achieving a competitive advantage. From a business rescue perspective, Rosslyn-Smith and Pretorius (2015) and Conradie and Lamprecht (2015) recognise the balanced view in line with section $7(\mathrm{k})$ of the Act: the view of not prioritising aligned with Chapter 6 of the legislation. In summation, it can be suggested that BRPs prioritise stakeholders during the business rescue process and appear to take note of section $7(\mathrm{k})$ of the Act which requires them to take a balanced approach.

Employment emerged as a theme in discussing the prioritisation of stakeholders. The aspect of employment is linked to the objective of business rescue and is also one of the indicators of a successful business rescue as put forth by Pretorius (2015). Within the literature Levenstein (2016) and Conradie and Lamprecht (2018) are in consensus with Pretorius that a successful business rescue will result in the preservation of jobs. The findings reflect the views of the participants, which are aligned with literature, in that employment is a key aspect of business rescue. The BRPs focus on ensuring that they save jobs, whether through the prioritisation of stakeholders or by taking a balanced approach.

\section{Stakeholder influence - Ranking}

The BRPs were requested to rank stakeholders in terms of their influence in a successful business rescue process.

The results below indicate responses from 10 participants out of the 13 interviewed. Three participants were firmly against the ranking of stakeholders as they noted that their rankings differ from case to case depending on the nature of the rescue. The 10 that provided rankings provided them based on their general experience from the business rescues that they had undertaken. In their rankings, they took cognisance that variations may occur. The results of the ranking are presented in Figure 2. The rankings in Figure 2 are based on the top three stakeholders of each participant.

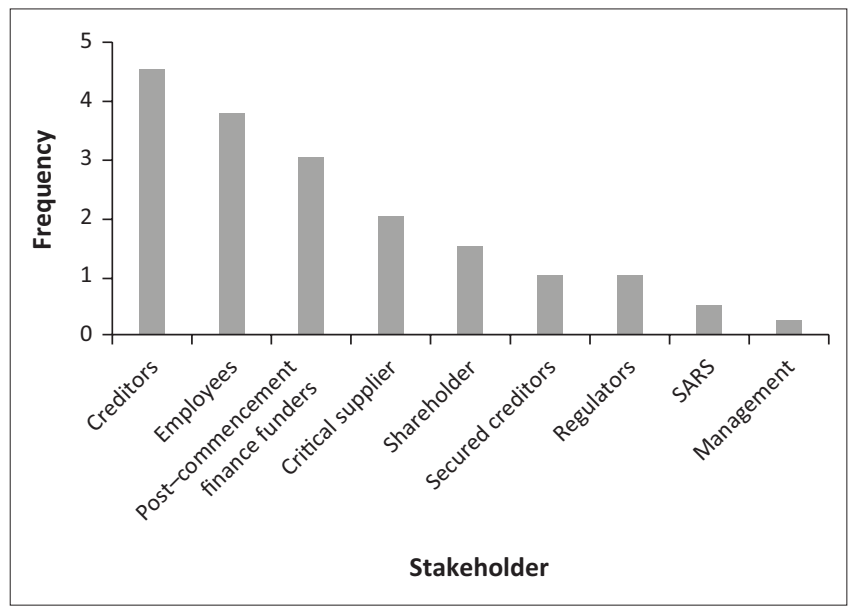

SARS, South African Revenue Services.

FIGURE 2: Stakeholder influence - Ranking.

\section{Stakeholder influence}

The discussion to follow reflects upon the stakeholder ranking in terms of influence but also seeks to understand why participants consider each stakeholder influential.

\section{Creditors, critical suppliers and secured creditors}

Creditors are ranked as the most influential stakeholder for their ability to vote and support the business operations. This aligns with Le Roux and Duncan (2013) and Pajunen (2006), confirming that suppliers provide resources that the organisation requires to support its operations. While in the literature the views may vary, the BRPs interviewed consider secured creditors influential but not as highly ranked as some other stakeholders.

Banks do not easily advance PCF to businesses in distress; security or surety is usually required before they decide to offer PCF (Pretorius \& Du Preez, 2013). It could be considered that although PCF is impactful, due to the challenges in obtaining PCF and other avenues that BRPs may pursue, PCF providers are ranked third after creditors and employees as the most influential stakeholders.

Employees occupy the second ranking in the listing of stakeholder influence according to the respondents. Employees are affected parties as defined by the Companies Act and thus have powers and rights protected by section 136 and section 144 of the Act. Levenstein (2016) views these powers as contributing to the influence that employees may have as they have to be consulted during the business rescue process. Additionally, their conditions of employment may not be altered unless agreed upon by mutual consent. Trahms et al. (2013), referring to their importance for a company in distress, note that the influence of employees and top management is evident.

The participants highlighted the importance of a 'jockey', meaning a person in the organisation that will provide management and leadership to support the BRP. The importance of management supports the view of Trahms et al. (2013) that top management is crucial and has an influence on a successful turnaround. Similar to employees, top management enjoy the rights and powers afforded by section 136 of the Companies Act which may lead to top management being influential (Joubert \& Loubser, 2016). The legislation provides them with the ability to exert their influence.

The terms 'government' and 'regulators' were used interchangeably and featured in all the rankings of this study. Although not highly ranked, regulators were viewed by the participants as key stakeholders in business rescue and as influential in the business rescue process. The findings indicate that the SARS may be particularly impactful as, in terms of the Income Tax Act, the SARS is a preferent creditor in liquidation but not in business rescue (Levenstein, 2016). As a creditor, the SARS may have the swing vote and the business rescue plan's acceptance may 
hinge on this vote. The appearance of the SARS as an influential stakeholder is supported by the legislation and the views of the participants.

Shareholders are also affected parties as defined by Chapter 6. From the ranking list, shareholders have been ranked fifth in terms of influence. It must be noted that shareholders may also be creditors but may have limited influence and BRPs do not focus on the shareholder when rescuing a company in distress.

This view mirrors the literature and legislation which limits the powers of the shareholder. Pajunen (2006) has an alternative view: shareholders have resource-based power derived from resources they hold and the knowledge they possess. This aspect has not been demonstrated clearly in our findings. Shareholder influence in business rescue may differ from that in a turnaround as Chapter 6, section 146 of the Companies Act plays an important role in the influence shareholders may exert in business rescue.

\section{Research proposition 3: Size of the claim, resources, networks, post-commencement finance, creditor security and rankings of creditors determine influence during the business rescue process}

The proposition seeks to identify the factors that contribute to the influence of stakeholders during the business rescue process. After determining the influence drivers, we discuss the role of the BRP as an orchestrator of a successful business rescue.

\section{Factors contributing to stakeholder influence}

The BRPs were requested to draw upon their experience and give a general view on the factors that contribute to stakeholder influence. Table 3 illustrates the factors that the BRPs considered relevant to a stakeholder's influence during business rescue. The table displays the source of the factors which may be resource, network based or legislative.

What is of interest in the findings is that security is ranked second. However, the respondents did not mention security

\begin{tabular}{|c|c|c|c|}
\hline Rank & Factor & Frequency & Source \\
\hline 1 & Creditor power from outstanding debt & 7 & Resource-based \\
\hline 2 & $\begin{array}{l}\text { Critical supplier - Ability to provide critical } \\
\text { goods or services }\end{array}$ & 4 & Resource-based \\
\hline 2 & PCF - Ability to provide PCF & 4 & Resource-based \\
\hline 2 & Voting interest - Ability to vote for the plan & 4 & Resource-based \\
\hline 2 & Security - Power leveraged through security & 4 & Resource-based \\
\hline 2 & Ability to support business continuity & 4 & Resource-based \\
\hline 3 & $\begin{array}{l}\text { Influence because of knowledge of legacy } \\
\text { issues }\end{array}$ & 1 & Network based \\
\hline 3 & $\begin{array}{l}\text { Regulatory powers for examples SARS, ESKOM, } \\
\text { other regulators }\end{array}$ & 1 & Legislation \\
\hline 3 & $\begin{array}{l}\text { Directors surety, invested in business want it } \\
\text { to work }\end{array}$ & 1 & Resource-based \\
\hline 3 & Ability to influence to implement the plan & 1 & All the above \\
\hline
\end{tabular}

to the same extent as the other factors that are ranked second such as suppliers, voting interest, PCF and the ability to support business continuity.

The top factor relates to the ability of the creditors to use the value of the outstanding amount to influence the voting process. This is essential to the adoption of the business rescue plan and is the first major step towards a successful business rescue.

The resource-based view dictates that stakeholders with resources essential to the organisation have a compelling lever to influence the organisation to recover from decline (Pajunen, 2006). The resource-based view amplifies the instrumental view which identifies stakeholders through their economic or financial impact (Donaldson \& Preston, 1995). Table 3 indicates that most of the factors identified by BRPs are resource-based factors.

\section{Business rescue practitioner's influence on the success of the business rescue}

Participants made reference to the competence and ethics of the BRP as a determining factor of the success of the business rescue. The main themes identified from the interviews were BRP expertise, BRP ethics and the Diener case.

\section{Business rescue practitioner expertise}

A BRP's expertise refers to the BRP, as a professional, being suitably qualified and skilled to take on the dynamic business rescue process. The BRP should be competent enough to ensure that an equitable outcome is achieved as required by the Companies Act in terms of section $7(\mathrm{k})$. The findings indicate that $62 \%$ of the respondents referred to BRP expertise and knowledge compared to $38 \%$ who did not refer to BRP expertise during the interviews.

\section{Business rescue practitioner ethics}

This theme relates to the ethics and values of the BRP in their conduct of the business rescue assignment. The expectation is that the BRP will act in the best interest of the stakeholders and act in an honest and trustworthy manner. The findings indicate that $77 \%$ of the respondents referred to BRP ethics compared to $23 \%$ who did not refer to BRP ethics during the interviews.

\section{Diener case}

In discussing the competence, skills and ethics of the BRP, discussions led to the question on the fees paid to BRPs. The Diener case makes it risky for a practitioner to charge fees to take on a business rescue that should be in liquidation. The BRP's fees and expenses are ranked preferably in business rescue but should they remain unpaid in a business rescue that goes to liquidation they will be treated as concurrent. The views of the participants were not unanimous. Some participants seemed to support the Diener judgement as a way to curb unethical BRPs. The neutral responses noted that as much as the judgement may curb unethical behaviour BRP fees still needed to be paid. 


\section{Conclusion}

\section{Stakeholder definition and identification}

BRPs consider affected parties to be the primary stakeholders within the business rescue process. Other stakeholders are considered as evidenced by the broad view reinforced by section $7(\mathrm{k})$ of the Companies Act which requires the BRP to balance the interests of all stakeholders.

Unexpectedly, customers were given the same level of importance as affected parties. This finding suggests that perhaps customers should be considered affected parties with the ability to vote on the business rescue plan, particularly where there are warranties or goods and services paid for before delivery.

\section{Stakeholder prioritisation}

In practice the business rescue process is dynamic; prioritisation is done to handle burning issues and to get the support of stakeholders who may be resourceful. Despite the prioritisation, BRPs try to act impartially in an attempt to balance the interests of all stakeholders.

\section{Factors contributing to stakeholder influence}

While network position and legislation-based influence are apparent in the business rescue process the resource-based view dominates the source of factors that result in stakeholder influence. Resource dependency is key to various aspects of a business rescue. Voting rules dictate how creditors, through their outstanding debts, vote to approve the plan. At the plan implementation phase, critical suppliers, PCF providers and employees play a role in providing resources to support the organisation in distress.

It became apparent during the study that BRPs are key stakeholders in business rescues. These BRPs should be expertly skilled and possess the appropriate qualifications and business knowledge to turn around a business in distress. The quality of the BRP may have dire consequences on the success of the rescue.

Ethical considerations also play a role in the BRP's ability to influence the business rescue process. Views from the BRPs interviewed indicated that some practitioners act unethically to drive their self-interested agenda of profit-making. They charge fees prolonging business rescue or where there is no hope of turning the business around. Although the Diener

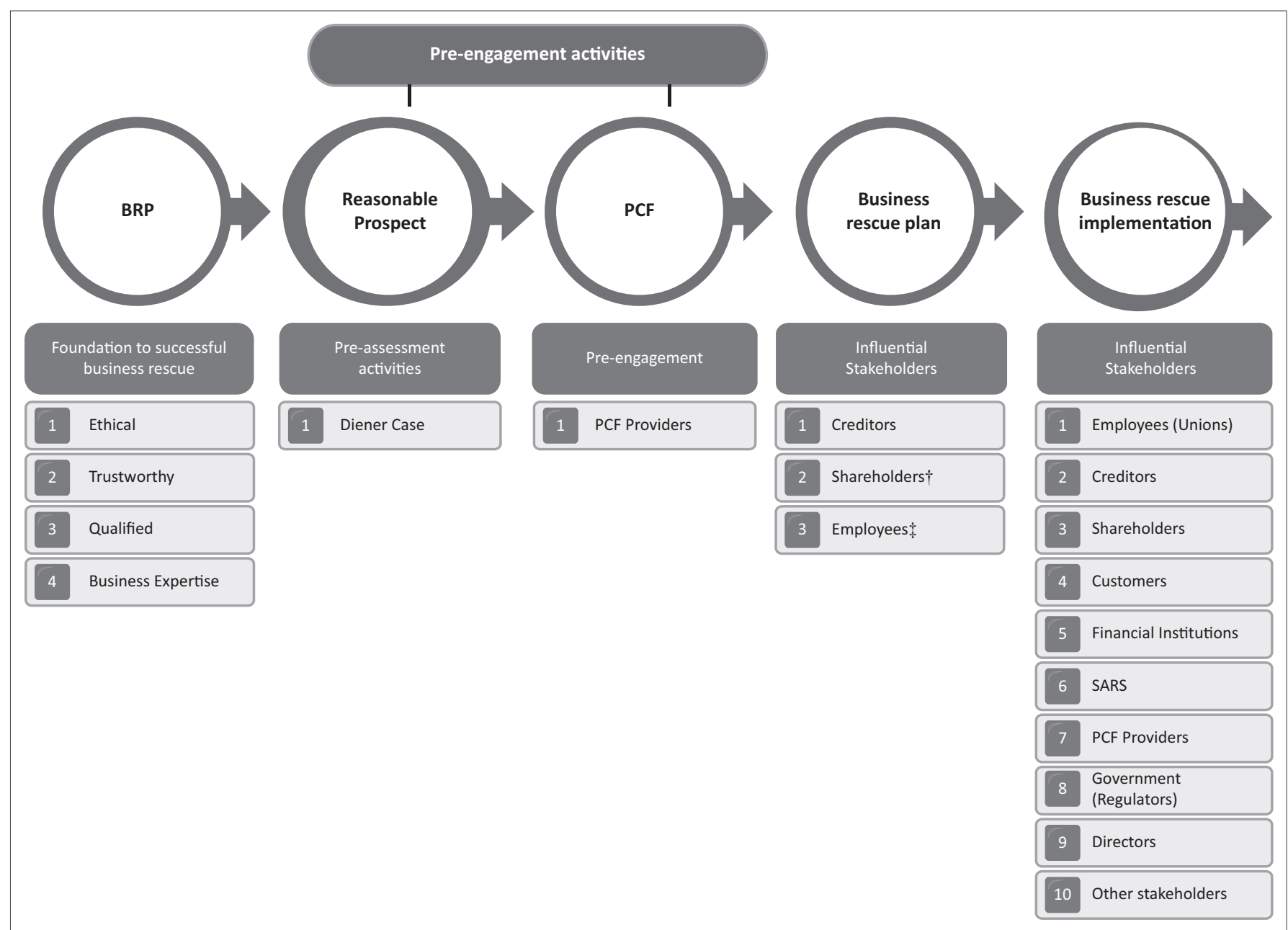

$\dagger$, Shareholders only vote on the plan if they are a creditor or if their rights as shareholders are impacted by the business rescue plan; $\ddagger$, Other stakeholders may change from rescue to rescue. SARS, South African Revenue Services.

FIGURE 3: Business rescue stakeholder analysis framework. 
judgement may make such practitioners cautious, the participants had mixed views on the judgement. Ultimately, the presence of BRPs that are unethical has an impact on the ability of the BRP to influence providers of PCF and other affected parties. A fully qualified, skilled and ethical BRP is thus the foundation for successful business rescue.

\section{Proposed framework}

This section presents a proposed conceptual framework that illustrates the roles of key stakeholders during business rescue. The framework presents a simplified timeline of the business rescue process with key aspects and influential stakeholders at different points in time. This framework (Figure 3) seeks to provide a foundation for further stakeholder analysis, identification, prioritisation and business rescue plan implementation. It may also be used as a basis for further academic research.

The conceptual framework draws on the findings discussed in the study. At the core of the framework is the BRP. The BRP has full management control, must be suitably qualified, skilled and ethical. The BRP forms the foundation of a successful business rescue. The pre-engagement activities bring into play the Diener judgement, implying that the BRP needs to be careful in ensuring a reasonable prospect of rescuing the business. The next phase of the framework reflects the views of most BRPs, that they will not undertake a business rescue without PCF.

Preparation of the business rescue plan is considered a key activity carried out by the BRP and it is instrumental to successful business rescue. The final vote to approve the business rescue plan lies with the creditors; therefore, creditors are influential in the business rescue plan adoption and implementation. In the implementation phase, stakeholders, including employees, regulators and the SARS, are considered key. The roles these key stakeholders play vary with each business rescue.

\section{Implications for business rescue practitioners}

It has been demonstrated that stakeholder management should be recognised as an activity that must be allocated time and resources as it has an impact on the success of the business rescue. The findings suggest that BRPs should consider canvassing for customer support as customers play a valuable role in supporting business continuity during distress periods. Finally, BRPs should recognise that different stakeholders are influential during different stages of the rescue and focus their efforts accordingly as indicated by the framework.

\section{Limitations}

The conclusions reached are based on the views of BRPs. These views may be influenced by their biases and perspectives, such as their bias towards the profession, their backgrounds and beliefs. The study is based on 13 BRPs and generalisation of the conclusions requires mindfulness of this fact. It is recommended that further empirical testing be considered. The sample consists of only BRPs; other stakeholders, for example financial institutions and attorneys, were not taken into account but may have different views.

\section{Recommendations for future research}

A study of stakeholders in business rescue from the perspective of other stakeholders, namely legal practitioners and credit insurers, is recommended. These stakeholders play a role in the business rescue process and could present views different from the BRPs. A quantitative study can be carried out to enhance the findings of this study. Regulators and customers have been identified as important role players prior to and during business rescue. Thus, empirical research would enhance an understanding of their influence and impact. Should customers be classified as affected parties, one could investigate how much monetary loss is incurred by customers in business rescue.

\section{Acknowledgements Competing interests}

The authors have declared that no competing interest.

\section{Author's contributions}

All authors contributed equally to this work.

\section{Ethical consideration}

This study was approved by the GIBS MBA Research Ethical Clearance Committee.

\section{Funding information}

This research received no specific grant from any funding agency in the public, commercial, or not-for-profit sectors.

\section{Data availability statement}

Data sharing is not applicable to this article as no new data were created or analysed in this study.

\section{Disclaimer}

The views and opinions expressed in this article are those of the authors and do not necessarily reflect the official policy or position of any affiliated agency of the authors.

\section{References}

Benedettini, O., Neely, A., \& Swink, M. (2015). Why do servitized firms fail? A riskbased explanation. International Journal of Operations \& Production Management, 35(6), 946-979. https://doi.org/10.1108/IJOPM-02-2014-0052

Braatvedt, K.J. (2017). The Diener judgement: Certainty at last. Retrieved 04 July 2018 , from https://www.tma-sa.com/info-centre/judgments-and-legal-articles.html

Bradstreet, R. (2010). The leak in the Chapter 6 lifeboat: Inadequate regulation of business rescue practitioners may adversely affect lenders' willingness and the growth of the economy. SA Mercantile Law Journal= SA Tydskrif vir Handelsreg, 22(2), 195-213.

Braun, V., \& Clarke, V. (2006). Using thematic analysis in psychology. Qualitative ResearchinPsychology, 3(2),77-101.https://doi.org/10.1191/1478088706qp0630a

Clarkson, M.E. (1995). A stakeholder framework for analysing and evaluating corporate social performance. Academy of Management Review, 20(1), 92-117. https://doi.org/10.5465/amr.1995.9503271994 
Conradie, S., \& Lamprecht, C. (2015). Business rescue: How can its success be evaluated at company level? Southern African Business Review, 19(3), 1-29.

Conradie, S., \& Lamprecht, C. (2018). What are the indicators of a successful business rescue in South Africa? Ask the business rescue practitioners. South African Journal of Economic and Management Sciences, 21(1), 1-12. https://doi.org/ 10.4102/sajems.v21i1.1726

D'Aveni, R.A., \& MacMillan, I.C. (1990). Crisis and the content of managerial communications: A study of the focus of attention of top managers in surviving and failing firms. Administrative Science Quarterly, 35(4), 634-657. https://doi.org/10.2307/2393512

Decker, C. (2016). Stakeholders' impact on turnaround performance: The case of German savings banks. Journal of Small Business Management, 56(4), 534-554. https://doi.org/10.1111/jsbm.12274

Donaldson, T., \& Preston, L.E. (1995). The stakeholder theory of the corporation: Concepts, evidence, and implications. Academy of management Review, 20(1), 65-91. https://doi.org/10.5465/amr.1995.9503271992

Du Preez, W. (2012). The status of post-commencement finance for business rescue in South Africa (Masters [MBA] dissertation), University of Pretoria, Pretoria.

Elo, S., Kääriäinen, M., Kanste, O., Pölkki, T., Utriainen, K., \& Kyngäs, H. (2014). Qualitative content analysis: A focus on trustworthiness. Sage Open, 4(1), 1-10. 2158244014522633

Fassin, Y. (2009). The stakeholder model refined. Journal of Business Ethics, 84(1), 113-135. https://doi.org/10.1007/s10551-008-9677-4

Freeman, R.E. (1984). Strategic management: A stakeholder approach. Boston, MA Pitman.

Freeman, R.E., Harrison, J.S., Wicks, A.C., Parmar, B.L., \& De Colle, S. (2010) Stakeholder theory: The state of the art. Cambridge: Cambridge University Press.

Friedman, A., \& Miles, S. (2002). Developing stakeholder theory. The Journal of Management Studies, 39(1), 1-21. https://doi.org/10.1111/1467-6486.00280

Ghazzawi, I.A. (2017). Organizational turnaround: A conceptual framework and research agenda. American Journal of Management, 17(7), 9-23. https://doi. org/10.33423/ajm.v17i7.1698

Harrison, J.S., Bosse, D.A., \& Phillips, R.A. (2010). Managing for stakeholders, stakeholder utility functions, and competitive advantage. Strategic Management Journal, 31(1), 58-74. https://doi.org/10.1002/smj.801

Henisz, W.J., Dorobantu, S., \& Nartey, L.J. (2014). Spinning gold: The financial return to stakeholder engagement. Strategic Management Journal, 35(12), 1727-1748. https://doi.org/10.1002/smj.2180

James, S.D. (2016). Strategic bankruptcy: A stakeholder management perspective Journal of Business Research, 69(2), 492-499. https://doi.org/10.1016/j. jbusres.2015.05.006

Jijana, C., Chetty, N., \& Karodia, A.M. (2016). Investigating the nature, purpose and effectiveness of business rescue in South Africa: Chapter 6 of Companies Act 71 of 2008 as amended. Singaporean Journal of Business, Economics and Management Studies, 51(3415), 1-39. https://doi.org/10.12816/0027222

Joubert, E.P., \& Loubser, A. (2016). Executive directors in business rescue: Employees or something else? De Jure, 49(1), 95-104. https://doi.org/10.17159/22257160/2016/v49n1a6

Le Roux, I., \& Duncan, K. (2013). The naked truth: Creditor understanding of business rescue: A small business perspective. The Southern African Journal of Entrepreneurship and Small Business Management, 6(1), 57-74. https://doi. org/10.4102/sajesbm.v6i1.33

Levenstein, E. (2016). An appraisal of the new South African business rescue procedure (Doctoral dissertation), University of Pretoria, Pretoria.

Mainardes, E.W., Alves, H., \& Raposo, M. (2012). A model for stakeholder classification and stakeholder relationships. Management Decision, 50(10), 1861-1879. https://doi.org/10.1108/00251741211279648
Miles, S. (2017). Stakeholder theory classification: A theoretical and empirical evaluation of definitions. Journal of Business Ethics, 142(3), 437-459. https://doi.org/10.1007/s10551-015-2741-y

Mitchell, R.K., Agle, B.R., \& Wood, D.J. (1997). Toward a theory of stakeholder identification and salience: Defining the principle of who and what really counts. Academy of Management Review, 22(4), 853-886. https://doi.org/10.5465/ Academy of Manage
amr.1997.9711022105

Pajunen, K. (2006). Stakeholder influences in organizational survival. Journal of Management Studies, 43(6), 1261-1288. https://doi.org/10.1111/j.1467-6486. Management

Pretorius, M. (2013). Tasks and activities of the business rescue practitioner: A strategy as practice approach. Southern African Business Review, 17(3), 1-26.

Pretorius, M. (2014). A competency framework for the business rescue practitioner profession. Professional Accountant, 14(2), 1-15. https://doi.org/10.4102/ac. v14i2.227

Pretorius, M. (2015). Business rescue status quo report. Retrieved 01 May 2018, from http://www.cipc.gov.za/files/4714/2866/7900/Report_Number_3_ammended_ 30032015.pdf

Pretorius, M. (2016). The debtor-friendly fallacy in business rescue: Agency theory moderation and quasi relationships. South African Journal of Economic and Management Sciences, 19(4), 479-496. https://doi.org/10.4102/sajems. v19i4.1385

Pretorius, M., \& Du Preez, W. (2013). Constraints on decision making regarding postcommencement finance in business rescue. The Southern African Journa of Entrepreneurship and Small Business Management, 6(1), 168-191. https://doi.org/10.4102/sajesbm.v6i1.39

Pretorius, M., \& Rosslyn-Smith, W. (2014). Expectations of a business rescue plan: International directives for Chapter 6 implementation. Southern African Business Review, 18(2), 108-139. https://doi.org/10.25159/1998-8125/5681

Priego, A.M., Lizano, M.M., \& Madrid, E.M. (2014). Business failure: Incidence of stakeholders' behavior. Academia, 27(1), 75-91. https://doi.org/10.1108/ARLA12-2013-0188

Rosslyn-Smith, W., \& Pretorius, M. (2015). Stakeholder expectations of the business rescue plan from a South African perspective. The Southern African Journal of Entrepreneurship and Small Business Management, $7(1), 1-35$. https://doi.org/10.4102/sajesbm.v7i1.4

Saunders, M.N., \& Lewis, P. (2012). Doing research in business and management: An essential guide to planning your project. Harlow: Pearson Education.

Smith, M., \& Graves, C. (2005). Corporate turnaround and financial distress. Managerial Auditing Journal, 20(3), 304-320. https://doi.org/10.1108/02686900 510585627

Statistics South Africa. (2017). The Quarterly Labour Force Survey - 4th Quarter 2017. Retrieved 23 April 2018, from http://www.statssa.gov.za/?p=10884

Tangpong, C., Abebe, M., \& Li, Z. (2015). A temporal approach to retrenchment and successful turnaround in declining firms. Journal of Management Studies, 52(5), 647-677. https://doi.org/10.1111/joms.12131

Trahms, C.A., Ndofor, H.A., \& Sirmon, D.G. (2013). Organizational decline and turnaround: A review and agenda for future research. Journal of Management, 39(5), 1277-1307. https://doi.org/10.1177/0149206312471390

World Bank. (2015). The World Bank principles for effective insolvency and creditor/ debtor rights systems (revised 2015). Retrieved 17 April 2018, from http:// siteresources.worldbank.org/EXTGILD/Resources/5807554-1357753926066/2015_ Revised_ICR_Principles(3).pdf

Zikmund, W., Babin, B., Carr, J., \& Griffin, M. (2013). Business research methods. Mason, $\mathrm{OH}$ : Cengage Learning. 